Chirurgia (2021) 116: 438-450

No. 4, July - August

Copyright $\odot$ Celsius

http://dx.doi.org/10.21614/chirurgia.116.4.438

\title{
Liver Resection for Metastases from Gastrointestinal Stromal Tumors: Does it Improve Long-Term Survival?
}

\author{
Alin Kraft ${ }^{1,2}$, Adina Croitoru ${ }^{3,4}$, Cristian Gheorghe ${ }^{5,6}$, Ioana Lupescu ${ }^{6,7}$, Mugur Grasu ${ }^{6,7}$, Dana Tomescu ${ }^{6,8}$, \\ Gabriela Droc ${ }^{6,8}$, Vlad Herlea ${ }^{4,9}$, Alexandru Barcu ${ }^{4,10}$, Irinel Popescu ${ }^{4,10}$, Florin Botea ${ }^{4,10^{*}}$ \\ 'Doctoral School in Medicine, "Titu Maiorescu" University, Bucharest, Romania \\ 2"Regina Maria" Military Emergency Hospital, Brașov, Romania \\ 3Department of Medical Oncology, "Fundeni" Clinical Institute, Bucharest, Romania \\ "Faculty of Medicine, University "Titu Maiorescu", Bucharest, Romania \\ ${ }^{5}$ Center of Gastroenterology and Hepatology, "Fundeni" Clinical Institute, Bucharest, Romania \\ "Carol Davila" University of Medicine and Pharmacy, Bucharest, Romania \\ 'Department of Medical Imaging, "Fundeni" Clinical Institute, Bucharest, Romania \\ ${ }^{8}$ Department of Anaesthesia and Intensive Care, "Fundeni" Clinical Institute, Bucharest, Romania \\ 'Department of Pathology "Fundeni" Clinical Institute, Bucharest, Romania \\ 10"Dan Setlacec" Center for General Surgery and Liver Transplant, "Fundeni” Clinical Institute, Bucharest, Romania
}

*Corresponding author:

Florin Botea, MD

Center of General Surgery and Liver Transplantation, Fundeni Clinical Institute; Soseaua Fundeni 258 Bucharest, Romania, 022328

E-mail: boteaflorin@yahoo.com

\section{Rezumat}

Supravietuirea pe termen lung este prelungită după rezectia hepatică pentru metastazele tumorilor gastrointestinale stromale?

Introducere sii Scop: Apariția inhibitorilor tirozin kinazei a modificat radical managementul tumorilor gastrointestinale stromale şi a ridicat controverse privind rolul rezecției hepatice în tratamentul metastazelor. Prezentul studiu îşi propune: să cerceteze existența unei prelungiri în supraviețuirea pe termen lung a pacienților $\mathrm{cu}$ metastaze hepatice ale tumorilor gastrointestinale stromale, supuşi rezecției în contextul terapiei multimodale, în comparație cu pacienții abordați numai prin terapie sistemică.

Materiale şi Metode: Folosind o bază retrospectivă, am identificat 57 patienți tratați în centrul nostru pe o perioadă de 12 ani: grupul A (n=31) supuşi rezecției hepatice alături de terapie sistemică şi grupul $B(n=26)$ care a urmat doar terapie sistemică. Pentru a obține un lot robust, necesar unei analize elocvente a supraviețuirii, am utilizat calculul unui scor de propensitate $\mathrm{cu}$ matching şi o selectie bootstrapping cu corectia erorilor Jackknifë astfel am creat un lot de studiu extins ce a cuprins 1000 pacienți virtuali. 
Rezultate:Supraviețiirea globală determinată pentru întreg lotul a fost de 47 luni (95\%CI:34-60); semnificativ crescută pentru grupul A (56 luni, 95\%CI:37-75) în comparație cu grupul B (38 luni, 95\%CI:19-56), ( $\mathrm{p}=0.007$, Log Rank test). Analiza multivariată a identificat un factor de risc: existența metastazelor hepatice sincrone la momentul diagnosticului tumorii primare.

Concluzii: Considerăm că rezecția hepatică precedată de terapia cu inhibitori ai Tirozin Kinazei este strategia terapeutică actuală ce aduce şansele adecvate spre o posibilă vindecăre şi prelungirea supraviețuirii, la pacienții selectați corespunzător, evaluați în cadrul unei comisii oncologice multidisciplinare.

Cuvinte cheie: tumori gastrointestinale stromale, hepatectomie, terapie multimodală, scor de propensitate cu matching, selecție bootstrapping cu corecția erorilor Jackknife, suraviețire

\begin{abstract}
Background \& Aims: The emergence of tyrosine kinase inhibitors, radically altered the management of GISTs and sparked controversy regarding the role of hepatic resection for metastatic tumors. This study aims to identify whether there is improvement in the overall survival of patients with gastrointestinal liver metastases, undergoing hepatic resection in the context of multimodal treatment strategy, as to those approached only by systemic therapy.

Methods: Using a retrospective database, we identified 57 patients treated at our center over a 12-year period: Group A ( $\mathrm{n}=31)$ underwent hepatic resection alongside systemic therapies, and B $(n=26)$ only systemic therapies. In order to obtain a more robust sample, needed for the survival analysis, we performed a propensity score matching and a bootstrapping selection with Jackknife correction for errors; thus, we created an extended sample of 1000 virtual patients.

Results: The overall survival measured in all patients was 47 months (95\%CI:34-60); significantly higher for group A (56 months, 95\%CI:37-75) compared to group B (38 months, 95\%CI:19-56), ( $p=0.007, \log$ Rank test). Multivariate analysis identified one risk factor: the presence synchronous liver metastases upon diagnosis of primary.

Conclusions: Liver resection following TKI therapy is the current mainstay of treatment strategy for potential cure and prolonged survival, in appropriately selected patients evaluated in an multidisciplinary tumor board.
\end{abstract}

Key words: gastrointestinal stromal tumors, hepatectomy, combined modality therapy, propensity score matching, bootstrapping selection with Jackknife correction for errors, survival

\section{Introduction}

Gastrointestinal stromal tumours (GISTs) arise from the interstitial cells of Cajal and are the most common type of mesenchymal tumours in the gastrointestinal tract (1), with an estimated incidence of 11.0-21.0 per million worldwide (2)

The incidence of distant metastases from GISTs has been reported to be as high as $23-47 \%(3,4)$. The most common sites of GIST metastases are the liver and peritoneum. Among the different sites, the liver accounted for $20-60 \%$ of all distant metastases $(3,5)$. GIST metastases to the liver (GLM) occur both synchronously and metachronously and are present at initial diagnosis between 15 and $20 \%$ of the time (6).

To treat liver metastases from GISTs, prior to 2000, hepatic resection was the only possible treatment option, which had a poor median survival of 15 months (7). The 
emergence of tyrosine kinase inhibitors (TKIs), such as imatinib mesylate, radically altered the management of GISTs and sparked controversy regarding the role of hepatic resection for metastatic tumours. TKIs significantly improved prognosis, achieving high disease control: $80 \%$ response rate and a significantly prolonged median survival time that has increased to 5 years (8).

Nowadays, Imatinib, a tyrosine kinase inhibitor (TKI), is the first-line treatment for advanced GIST (9). However, despite its potent efficacy, complete responses are rare, and at least half of the patients develop resistance to imatinib within 2 years of initiating treatment because of secondary gene mutations (10). The limitation of TKI therapy has prompted the reassessment of surgery for advanced GIST, but opinions differ. Some suggested that only patients with stable or limited progression disease on TKI therapy could benefit from debulking surgery (11), whereas others found that when complete resection could be achieved, even those with progressing disease would benefit (12). From an anatomical perspective, GLM are easier to define and assess than those in the peritoneum. This feature gives the first, greater possibility of complete resection, revealing a special subset of advanced GIST where surgery has a greater role to play: by the means of the liver-directed therapies available, leading to the importance of establishing a coordinated approach to GLM (6).

Nowadays, there is a lack of randomised clinical trials that target the therapy model composed of hepatic resection with TKIs. Thus, leading to a controversy regarding the influence of liver resection within a multimodal treatment plan, concerning: efficacy (13), as well as timing (14).

This study aims to identify whether there is improvement in the overall survival of patients with GLM, undergoing hepatic resection in the context of multimodal treatment strategy, as to those approached only by systemic therapy.

\section{Methods}

This retrospective cohort study was performed at a tertiary referral centre for hepato-biliopancreatic surgery and liver transplant. No ethical concerns were raised by the institution's Ethics Committee.

\section{Patients}

Using a retrospective institutional database, we identified 57 patients undergoing multimodal treatment for histologically diagnosed GLM at our centre over a 12-year period, between $1^{\text {st }}$ of January 2007 and $31^{\text {st }}$ of December 2018. We categorised patients in two groups, based on their treatment approach: Group A ( $\mathrm{n}=31$ ) underwent hepatic resection alongside systemic therapies, and Group B ( $n=26)$ underwent only systemic therapies. For each and every one of the patients, the treatment approach was determined by a multidisciplinary team (hepato-bilio-pancreatic surgeon, digestive oncologist, interventional radiologist).

Patients declared unfit for surgery, were directed to the systemic therapy group because of the following reasons: in 6 patients the liver resection was technically unfeasible (due to high metastases burden: multiple, disseminated, great dimensions), in 8 patients the metastases resection was unfeasible, due to presence of extrahepatic metastases with high burden (multiple, disseminated), resection of the primary tumour was unfeasible among 3 patients, 7 patients refused the surgical act, and 1 patient was declared unfit for surgery due to comorbidities.

In order reduce the bias of patient selection, we excluded from the study:

- those patients $(n=7)$ from Group B, considered as "end stage disease" upon admission in our institute, due to the high tumour burden and great extent of the metastatic disease.

- those patients $(n=3)$ from Group A, that underwent other forms of liver-directed therapies besides resection (radiofrequency ablation, whole liver trans- 
plantation), or as a complement to liver resection (resection and ablation);

\section{Analyzed Variables}

1. Standard demographic and clinicopathologic data were collected, including: gender, age, ASA class, comorbidities [scored using the Charlson Comorbidity Index], and ECOG performance status.

2. For primary tumor characteristics: origin of primary tumor (foregut: esophagus, stomach, liver, gallbladder, pancreas, caudal portion of the duodenum, midgut: distal duodenum, jejunum, ileum, cecum, appendix, ascending colon, proximal $2 / 3$ of transverse colon, and hindgut: distal transverse colon, descending colon, sigmoid, anorectum), presence of symptoms, and existence of synchronous liver, or extrahepatic metastases.

3. Resection of primary tumor: resection status, tumor grading, NIH risk group, presence of lymph node metastases.

4. GIST liver metastases data included: number, size, location, hepatic involvement, grading, number of mitoses, Ki-67 index, and presence of extrahepatic metastases.

5. For patients undergoing liver resection, we collected the following data: number of synchronous resections (of both primary and liver metastases), minimally invasive approach, portal vein embolisation, intraoperative ultrasound, extent and type of resection (non-anatomic wedge, single segmentectomy, bi-segmentectomy, right hepatectomy, left hepatectomy, extended right hepatectomy, extended left hepatectomy, and extended central hepatectomy), resection margin status, intent of treatment, type of postoperative complications and their management, and mortality rates.

Postoperative complications: were scored according to the Clavien-Dindo classification as no complication or complication grades I to V (15).

6. For patients undergoing systemic therapy we collected: the type of therapy administered, response of liver metastasis; related morbidity. Tyrosine kinase inhibitor therapy included: Imatinib, Sunitinib and Regorafenib. Patients undergoing chemotherapy received: ifosamide, taxotere, and gemcitabine.

7. Upon long-term results we collected: the date of death.

\section{Study Endpoints and Baseline Definitions}

The endpoint of the study was Overall Survival (OS), defined as the time from randomisation until death from any cause (16); measured form the baseline: date of GLM diagnosis, until: date of death - obtained officially from the "Directorate for People's Registry and Databases Management", on the 13th of April 2019. Follow-up evaluation results were obtained by review of the patient's medical records and/or by personal telephone interview conducted during April 2019. The response to the systemic treatment was classified according to the Response Evaluation Criteria in Solid Tumors (RECIST) (17).

\section{Statistical Analyses}

All statistical analyses were performed using IBM SPSS Statistics for Windows (version 23.0, IBM, Chicago, IL). Categorical variables were described in frequencies and percentages. Continuous variables were represented as mean \pm SD or median and range. Categorical variables were compared using the Chi-Square test and Fisher's exact test. Continuous variables with quasi-normal distributions were compared using Student's $\mathrm{T}$ test and those with a severe deviation from normality, with appropriate nonparametric tests.

Overall survival (OS) was estimated using a Kaplan-Meyer survival analysis considering the time-to-event in months. The differences in survival were tested using the log-rank test.

A propensity score matching was performed to reduce the patient selection bias. This methodology has been shown to greatly 
reduce effect size bias and gives nonrandomised studies experimental design characteristics. However, it's main drawback is: that due to the reduction in sample size, the studies will likely develop a decrease in terms of the statistical power analysis. The propensity score matching was performed with Python extension for SPSS. Covariates used to calculate the propensity score were: not only those based upon previously published studies (8), but also upon the ones that we considered adequate. At first, the propensity score was estimated using logistic regression. The covariates used in this step were: age, Charlson Comorbidity Score, ECOG Performance Status, $\mathrm{NIH}$ risk group, hepatic involvement at diagnosis, grading of liver metastasis, and presence of extrahepatic metastases. After estimating the propensity score, we matched the patients originating from the two groups using a one-to-one nearest neighbour matching with a caliper of 0.15 . After employing this procedure, we have obtained a $49 \%$ matching of cases from the sample (28 patients, 14 from each group).

In order to obtain a more robust sample, needed imperatively for the analysis of the differences in survival between the two groups and for identifying the factors associated with improved survival, we performed a bootstrapping selection with Jackknife correction for errors $(18,19)$. Thus, we created an extended sample of 1000 virtual patients, on which we performed again the propensity score matching, using the same covariates and caliper as previously mentioned, obtaining a $49 \%$ matching of cases (488 virtual patients in total, 244 from each group). The survival analysis was conducted on the extended matched sample (488 virtual patients).

Factors potentially associated with improved survival were analyzed using the Cox proportional hazard model with forward stepwise selection (on the original sample and on the matched sample). All variables were included in a univariate analysis and those with a $\mathrm{p}$-value of less than 0.05 were used in the multivariate analysis. Results were expressed as hazard ratio (HR) with a 95\% confidence interval
(CI). For all analyses, p-values $<0.05$ were considered statistically significant.

\section{Results}

The baseline characteristics of the unmatched sample (57 patients) are presented in Table 1.

\section{Quality Assessment of Propensity Scores}

In determining the propensity score we used the following covariates: (1) age, (2) Charlson Comorbidity Score, (3) ECOG Performance Status, (4) NIH risk group, (5) hepatic involvement at diagnosis, (6) grading of liver metastasis, and (7) presence of extrahepatic metas ${ }^{-}$ tases. Using these covariates we performed a logistic regression, saving predicted probabilities and logit transformations given the fact that they are used in the matching process (propensity score). The dependent variable was specified as the patient's treatment group. Afterwards, we examined the logistic regression model in order to assess the quality of propensity scores. First, we compared the correct classification of participants to groups to the null hit rate, and we discovered a $29 \%$ improvement (79\% versus 50\%). An inferential goodness-of-fit test (Hosmer-Lemeshow) was also performed and suggested good model fit Chi-square $=3.377(p=0.848)$. This apparently implied that the treatment approach was not determined randomly, and therefore can be reasonably predicted by the result of the covariates used in the estimation of propensity scores. The differences in the likelihood of undergoing hepatic resection or not (i.e. selection bias) were compared afterwards using an independent samples t-test. This initial assessment is important for evaluating the magnitude of bias and any improvement after the propensity score matching. Results indicated the groups were statistically different in their propensity scores or initial likelihood of being selected into group A $(p<0.001, \mathrm{SMD}=1.316)$. This difference in SMD (standardized mean difference) suggests that the two groups should not be directly compared when estimating treatment effects. 
Table 1. Baseline characteristics of the patients before score matching

\begin{tabular}{|c|c|c|c|c|}
\hline Categorical covariates & $\begin{array}{c}\text { Total (\%) } \\
(\mathrm{n}=57)\end{array}$ & $\begin{array}{l}\text { Group A (\%) } \\
(\mathrm{n}=31)\end{array}$ & $\begin{array}{l}\text { Group B (\%) } \\
(\mathrm{n}=26)\end{array}$ & p-value* \\
\hline Gender (male) & $47 \%$ & $45 \%$ & $50 \%$ & 0.793 \\
\hline ASA score $(>=3)$ & $14 \%$ & $7 \%$ & $23 \%$ & 0.078 \\
\hline \multicolumn{5}{|l|}{ Charlson Comorbidity Score } \\
\hline $6-7$ & $37 \%$ & $48 \%$ & $23 \%$ & \\
\hline $8-9$ & $51 \%$ & $48 \%$ & $54 \%$ & 0.029 \\
\hline$\geq 10$ & $12 \%$ & $4 \%$ & $23 \%$ & \\
\hline \multicolumn{5}{|l|}{ ECOG Performance Status } \\
\hline 0 & $35 \%$ & $26 \%$ & $46 \%$ & \\
\hline 1 & $51 \%$ & $64 \%$ & $35 \%$ & 0.076 \\
\hline 2 & $12 \%$ & $7 \%$ & $19 \%$ & \\
\hline 3 & $2 \%$ & $3 \%$ & $0 \%$ & \\
\hline \multicolumn{5}{|l|}{ Origin of Primary Tumor } \\
\hline Foregut & $40 \%$ & $45 \%$ & $35 \%$ & \\
\hline Midgut & $53 \%$ & $52 \%$ & $54 \%$ & 0.407 \\
\hline Hindgut & $7 \%$ & $3 \%$ & $11 \%$ & \\
\hline Symptomatic Primary Tumor (yes) & $93 \%$ & $94 \%$ & $92 \%$ & 0.855 \\
\hline Resection of Primary Tumor (yes) & $88 \%$ & $97 \%$ & $77 \%$ & 0.039 \\
\hline \multicolumn{5}{|l|}{ Primary Tumor Grading } \\
\hline G1 & $37 \%$ & $36 \%$ & $39 \%$ & \\
\hline G2 & $63 \%$ & $64 \%$ & $61 \%$ & 0.816 \\
\hline \multicolumn{5}{|l|}{ NIH Risk Group } \\
\hline Low & $12 \%$ & $13 \%$ & $12 \%$ & \\
\hline Intermediate & $19 \%$ & $19 \%$ & $19 \%$ & 0.987 \\
\hline High & $69 \%$ & $68 \%$ & $69 \%$ & \\
\hline $\begin{array}{l}\text { Lymph Node Metastasis upon Resection } \\
\text { of Primary (yes) }\end{array}$ & $21 \%$ & $19 \%$ & $26 \%$ & 0.499 \\
\hline $\begin{array}{l}\text { Synchronous Liver Metastases upon } \\
\text { Diagnosis of Primary (yes) }\end{array}$ & $49 \%$ & $61 \%$ & $35 \%$ & 0.040 \\
\hline \multicolumn{5}{|l|}{ Synchronous Extrahepatic Metastases } \\
\hline upon Diagnosis of Primary (yes) & $23 \%$ & $13 \%$ & $35 \%$ & 0.050 \\
\hline \multicolumn{5}{|l|}{ Number of Hepatic Metastases Upon Diagnosis } \\
\hline Solitary & $30 \%$ & $45 \%$ & $12 \%$ & \\
\hline $2-4$ & $14 \%$ & $13 \%$ & $15 \%$ & 0.020 \\
\hline$>4$ & $56 \%$ & $42 \%$ & $73 \%$ & \\
\hline \multicolumn{5}{|l|}{ Hepatic Involvement at Diagnosis } \\
\hline$<25 \%$ & $62 \%$ & $61 \%$ & $61 \%$ & \\
\hline $25-50 \%$ & $33 \%$ & $32 \%$ & $35 \%$ & 0.902 \\
\hline $50-75 \%$ & $5 \%$ & $7 \%$ & $4 \%$ & \\
\hline Location of Liver Metastases Bilobar & $63 \%$ & $52 \%$ & $77 \%$ & 0.044 \\
\hline \multicolumn{5}{|l|}{ Grading of Liver Metastasis } \\
\hline $\mathrm{G} 1$ & $32 \%$ & $29 \%$ & $35 \%$ & \\
\hline G2 & $68 \%$ & $71 \%$ & $65 \%$ & 0.777 \\
\hline \multicolumn{5}{|l|}{ Ki-67 of Liver Metastases } \\
\hline$<8$ & $4 \%$ & $3 \%$ & $4 \%$ & \\
\hline$\geq 8$ & $19 \%$ & $16 \%$ & $23 \%$ & 0.789 \\
\hline Unknown & $77 \%$ & $81 \%$ & $73 \%$ & \\
\hline $\begin{array}{l}\text { Extrahepatic Metastases upon Diagnosis } \\
\text { of the Liver Metastases (yes) }\end{array}$ & $40 \%$ & $32 \%$ & $50 \%$ & 0.138 \\
\hline \multicolumn{5}{|l|}{ Continuous covariates } \\
\hline Age in years (mean $\pm S D$ ) & $56 \pm 13$ & $52 \pm 13$ & $62 \pm 12$ & 0.005 \\
\hline $\begin{array}{l}\text { Size of the Largest Liver Metastasis }(\mathrm{cm}) \\
\text { (mean } \pm \mathrm{SD})\end{array}$ & $5.54 \pm 4.85$ & $6.96 \pm 5.73$ & $3.85 \pm 2.78$ & 0.011 \\
\hline $\begin{array}{l}\text { Number of Mitoses of Liver Metastasis } \\
\text { (mean } \pm \text { SD) }\end{array}$ & $8.79 \pm 5.96$ & $10.35 \pm 7.19$ & $6.92 \pm 3.29$ & 0.022 \\
\hline
\end{tabular}




\section{Nearest Neighbor Matching Within a Specified Caliper}

Therefore, propensity scores were used to match thepatients from group A to those in group B. Because, even in a large sample, an exact match is almost impossible to obtain, we decided to specify a-priori: a distance measure (a caliper). Specifically, we used a caliper of 0.15 standard deviations of this score, as a reasonable distance for reducing bias between groups (a larger value of the caliper will lead to more pairs matched, but with a less power of bias reduction).

\section{Post-matching Analyses to Evaluate Balance}

In order to evaluate balance as a result of the propensity score matching model, literature (20-22) suggests that: the standardised difference in the mean propensity score between the two groups should be less than 0.20 and the ratio of the propensity score variances in both groups should be near one (the recommended limits are $0.80-1.20$ ). For covariates, continuous or categorical, statistical differences should not be significant in the matched sample. The results of balance evaluation is presented in Table 2.1. and Table 2.2. Once balance is achieved on the propensity scores and covariates, groups can be directly compared on the outcome of interest (overall survival and factors potentially associated with better survival).

The characteristics of the administered liver-directed and systemic therapy before and after matching, are shown in Table 3.

\section{Liver Resection Characteristics in the Matched Sample}

$36 \%$ of patients in Group A underwent resection of the primary tumor and resection of synchronous liver metastases during the same operative procedure, $7 \%$ of patients were approached by the means of minimally invasive surgery, $3 \%$ were subjected to portal vein embolization, prior to the surgical intervention, and $32 \%$ received ultrasonographically guided liver resection. $71 \%$ of patients underwent minor resections, 29\% whereas received major resections. $71 \%$ received a wedge resection, single, and/or bi-segmentectomy. 13\% received a right hemihepatectomy; 7\% a left hemihepatectomy; $3 \%$ an extended right hemihepatectomy; $3 \%$ an extended left hemihepatectomy; $3 \%$ an extended central hepatectomy.

R0 resection was achieved in $97 \%$ of patients, in spite of the fact that $13 \%$ underwent hepatic resection with the plan of surgical debulking.

Postoperative complications occurred in $42 \%$ of patients. Dindo-Clavien Grade I or II complications were encountered in $19 \%$ of patients, whereas complications greater than Grade IIIa, occurred in $23 \%$ of patients, thus leading to the need of management, performed by: endoscopic, or radiologic reinterventions on $10 \%$ patients, whereas $13 \%$ patients required reoperation. Postoperative mortality rate was $3 \%$, due to hepatic failure.

\section{Survival Comparison for the Unmatched Sample}

The OS measured in all patients was 51 months (95\% CI: 40-62). There was a signifi-

Table 2.1. Propensity score balance before and after matching

\begin{tabular}{|c|c|c|c|c|c|c|c|c|}
\hline & \multicolumn{4}{|c|}{$\begin{array}{l}\text { Before matching } \\
\text { (57 patients) }\end{array}$} & \multicolumn{4}{|c|}{$\begin{array}{l}\text { After matching on extended sample } \\
\text { (488 virtual patients) }\end{array}$} \\
\hline & $\begin{array}{l}\text { Group A } \\
(n=31)\end{array}$ & $\begin{array}{l}\text { Group B } \\
(n=26)\end{array}$ & SMD & $\begin{array}{l}\text { Variance } \\
\text { ratio }\end{array}$ & $\begin{array}{l}\text { Group A } \\
(n=244)\end{array}$ & $\begin{array}{l}\text { Group B } \\
(n=244)\end{array}$ & $\begin{array}{l}\text { SMD } \\
\text { ratio }\end{array}$ & Variance \\
\hline $\begin{array}{l}\text { Propensity score } \\
\text { (Mean } \pm \text { SD) }\end{array}$ & $0.717 \pm 0.260$ & $0.337 \pm 0.241$ & 1.25 & 1.07 & $0.485 \pm 0.204$ & $0.455 \pm 0.199$ & 0.14 & 1.02 \\
\hline
\end{tabular}


Table 2.2. Covariates score balance before and after matching

\begin{tabular}{|c|c|c|c|c|c|c|}
\hline \multirow[b]{2}{*}{ Categorical covariates } & \multirow[b]{2}{*}{$\begin{array}{l}\text { Group A (\%) } \\
\qquad(n=31)\end{array}$} & \multicolumn{2}{|c|}{$\begin{array}{l}\text { Before matching } \\
\text { (57 patients) }\end{array}$} & \multicolumn{3}{|c|}{$\begin{array}{l}\text { After matching on extended sample } \\
\text { (488 virtual patients) }\end{array}$} \\
\hline & & $\begin{array}{l}\text { Group B (\%) } \\
(n=26)\end{array}$ & p-value* & $\begin{array}{l}\text { Group A (\%) } \\
(n=244)\end{array}$ & $\begin{array}{l}\text { Group B (\%) } \\
(n=244)\end{array}$ & p-value* \\
\hline ASA score $(\geq 3)$ & $7 \%$ & $23 \%$ & 0.078 & $14 \%$ & $22 \%$ & 0.500 \\
\hline $\begin{array}{l}\text { Charlson Comorbidity Score } \\
\quad 6-7 \\
\quad 8-9 \\
>10\end{array}$ & $\begin{array}{c}48 \% \\
48 \% \\
4 \%\end{array}$ & $\begin{array}{l}23 \% \\
54 \% \\
23 \% \\
\end{array}$ & 0.029 & $\begin{array}{l}29 \% \\
64 \% \\
7 \%\end{array}$ & $\begin{array}{l}29 \% \\
57 \% \\
14 \%\end{array}$ & 0.822 \\
\hline $\begin{array}{c}\text { ECOG Performance Status } \\
0 \\
1 \\
2 \\
3 \\
\end{array}$ & $\begin{array}{c}26 \% \\
64 \% \\
7 \% \\
3 \% \\
\end{array}$ & $\begin{array}{c}46 \% \\
35 \% \\
19 \% \\
0 \% \\
\end{array}$ & 0.076 & $\begin{array}{l}35 \% \\
43 \% \\
15 \% \\
7 \% \\
\end{array}$ & $\begin{array}{c}29 \% \\
43 \% \\
28 \% \\
0 \% \\
\end{array}$ & 0.620 \\
\hline $\begin{array}{l}\text { Origin of Primary Tumor } \\
\text { Foregut } \\
\text { Midgut } \\
\text { Hindgut }\end{array}$ & $\begin{array}{c}45 \% \\
52 \% \\
3 \%\end{array}$ & $\begin{array}{l}35 \% \\
54 \% \\
11 \% \\
\end{array}$ & 0.407 & $\begin{array}{l}28 \% \\
64 \% \\
7 \%\end{array}$ & $\begin{array}{l}14 \% \\
65 \% \\
21 \% \\
\end{array}$ & 0.435 \\
\hline $\begin{array}{l}\text { Symptomatic Primary Tumor (yes) } \\
\text { Resection of Primary Tumor (yes) }\end{array}$ & $\begin{array}{l}94 \% \\
97 \% \\
\end{array}$ & $\begin{array}{l}92 \% \\
77 \% \\
\end{array}$ & $\begin{array}{l}0.855 \\
0.039 \\
\end{array}$ & $\begin{array}{l}100 \% \\
100 \% \\
\end{array}$ & $\begin{array}{l}93 \% \\
72 \% \\
\end{array}$ & $\begin{array}{l}0.309 \\
0.098 \\
\end{array}$ \\
\hline $\begin{array}{l}\text { Primary Tumor Grading } \\
\text { G1 } \\
\text { G2 }\end{array}$ & $\begin{array}{l}36 \% \\
64 \% \\
\end{array}$ & $\begin{array}{l}39 \% \\
61 \% \\
\end{array}$ & 0.816 & $\begin{array}{l}29 \% \\
71 \%\end{array}$ & $\begin{array}{l}36 \% \\
64 \% \\
\end{array}$ & 0.686 \\
\hline $\begin{array}{l}\text { NIH Risk Group } \\
\text { Low } \\
\text { Intermediate } \\
\text { High }\end{array}$ & $\begin{array}{l}13 \% \\
19 \% \\
68 \% \\
\end{array}$ & $\begin{array}{l}12 \% \\
19 \% \\
69 \% \\
\end{array}$ & 0.987 & $\begin{array}{l}14 \% \\
14 \% \\
72 \% \\
\end{array}$ & $\begin{array}{l}7 \% \\
29 \% \\
64 \% \\
\end{array}$ & 0.591 \\
\hline $\begin{array}{l}\text { Lymph Node Metastasis upon } \\
\text { Resection of Primary (yes) }\end{array}$ & $19 \%$ & $26 \%$ & 0.499 & $22 \%$ & $28 \%$ & 0.511 \\
\hline $\begin{array}{l}\text { Synchronous Liver Metastases upon } \\
\text { Diagnosis of Primary (yes) }\end{array}$ & $61 \%$ & $35 \%$ & 0.040 & $43 \%$ & $43 \%$ & 1.000 \\
\hline $\begin{array}{l}\text { Synchronous Extrahepatic Metastases } \\
\text { upon Diagnosis of Primary (yes) }\end{array}$ & $13 \%$ & $35 \%$ & 0.050 & $22 \%$ & $50 \%$ & 0.115 \\
\hline $\begin{array}{l}\text { Number of Hepatic Hetastases Upon } \\
\text { Diagnosis } \\
\text { Solitary } \\
2-4 \\
>4\end{array}$ & $\begin{array}{l}45 \% \\
13 \% \\
42 \%\end{array}$ & $\begin{array}{l}12 \% \\
15 \% \\
73 \%\end{array}$ & 0.020 & $\begin{array}{l}14 \% \\
14 \% \\
72 \%\end{array}$ & $\begin{array}{l}22 \% \\
14 \% \\
64 \%\end{array}$ & 0.881 \\
\hline $\begin{array}{l}\text { Hepatic Involvement at Diagnosis } \\
<25 \% \\
25-50 \% \\
50-75 \%\end{array}$ & $\begin{array}{c}61 \% \\
32 \% \\
7 \%\end{array}$ & $\begin{array}{c}61 \% \\
35 \% \\
4 \%\end{array}$ & 0.902 & $\begin{array}{c}71 \% \\
29 \% \\
0 \%\end{array}$ & $\begin{array}{c}50 \% \\
43 \% \\
7 \%\end{array}$ & 0.381 \\
\hline Location of Liver Metastases Bilobar & $52 \%$ & $77 \%$ & 0.044 & $71 \%$ & $71 \%$ & 1.000 \\
\hline $\begin{array}{l}\text { Grading of Liver Metastasis } \\
\text { G1 } \\
\text { G2 }\end{array}$ & $\begin{array}{l}29 \% \\
71 \%\end{array}$ & $\begin{array}{l}35 \% \\
65 \%\end{array}$ & 0.777 & $\begin{array}{l}22 \% \\
78 \%\end{array}$ & $\begin{array}{l}28 \% \\
72 \%\end{array}$ & 0.663 \\
\hline $\begin{array}{l}\text { Ki-67 of Liver Metastases } \\
\quad<8 \\
\geq 8 \\
\text { Unknown }\end{array}$ & $\begin{array}{c}3 \% \\
16 \% \\
81 \%\end{array}$ & $\begin{array}{c}4 \% \\
23 \% \\
73 \%\end{array}$ & 0.789 & $\begin{array}{c}- \\
21 \% \\
79 \%\end{array}$ & $\begin{array}{c}7 \% \\
43 \% \\
50 \%\end{array}$ & $0 . \overline{236}$ \\
\hline $\begin{array}{l}\text { Extrahepatic Metastases upon } \\
\text { Diagnosis of the Liver Metastases (yes) }\end{array}$ & $32 \%$ & $50 \%$ & 0.138 & $36 \%$ & $57 \%$ & 0.256 \\
\hline $\begin{array}{l}\text { Continuous covariates } \\
\text { Age in vears (mean }+S D)\end{array}$ & $52+13$ & $62+12$ & 0005 & $57+9$ & $59+14$ & 0643 \\
\hline $\begin{array}{l}\text { Size of the Largest Liver Metastasis } \\
(\mathrm{cm})(\text { mean } \pm \mathrm{SD})\end{array}$ & $6.96 \pm 5.73$ & $3.85 \pm 2.78$ & 0.011 & $4.78 \pm 4.11$ & $4.11 \pm 3.46$ & 0.641 \\
\hline $\begin{array}{l}\text { Number of Mitoses of Liver Metastasis } \\
(\text { mean } \pm S D \text { ) }\end{array}$ & $10.35 \pm 7.19$ & $6.92 \pm 3.29$ & 0.022 & $10.36 \pm 5.28$ & $6.86 \pm 2.71$ & 0.040 \\
\hline
\end{tabular}


Table 3. Characteristics of the administered liver-directed and systemic therapy before and after matching

\begin{tabular}{|c|c|c|c|c|c|c|}
\hline \multirow[b]{2}{*}{ Categorical covariates } & \multicolumn{3}{|c|}{$\begin{array}{l}\text { Before matching } \\
\text { (57 patients) }\end{array}$} & \multicolumn{3}{|c|}{$\begin{array}{l}\text { After matching on extended sample } \\
\text { (488 virtual patients) }\end{array}$} \\
\hline & $\begin{array}{l}\text { Group A (\%) } \\
\quad(n=31)\end{array}$ & $\begin{array}{l}\text { Group B (\%) } \\
\quad(n=26)\end{array}$ & p-value* & $\begin{array}{l}\text { Group A (\%) } \\
(n=244)\end{array}$ & $\begin{array}{l}\text { Group B (\%) } \\
(n=244)\end{array}$ & p-value * \\
\hline \multicolumn{7}{|l|}{ Systemic Therapy } \\
\hline Yes & $65 \%$ & $100 \%$ & 0.047 & $71 \%$ & $100 \%$ & 0.098 \\
\hline No & $35 \%$ & - & - & $29 \%$ & - & - \\
\hline \multicolumn{7}{|c|}{ Response of GLM to Systemic Therapy } \\
\hline Progressive disease & - & $27 \%$ & - & - & $21 \%$ & - \\
\hline Stable disease & $22 \%$ & $27 \%$ & 0.976 & $21 \%$ & $21 \%$ & 1.000 \\
\hline Partial response & $10 \%$ & $46 \%$ & $<0.001$ & $7 \%$ & $58 \%$ & $<0.001$ \\
\hline Complete response & $68 \%$ & - & - & $72 \%$ & - & - \\
\hline \multicolumn{7}{|c|}{ Systemic Therapy Related Morbidity $(n=46)$} \\
\hline Yes & $15 \%$ & $15 \%$ & 1.000 & $10 \%$ & $21 \%$ & 0.437 \\
\hline No & $85 \%$ & $85 \%$ & & $90 \%$ & $79 \%$ & \\
\hline
\end{tabular}

cantly higher OS for group A (65 months, 95\% CI: 47-82) compared to group B (35 months, 95\%CI: 22-47), ( $\mathrm{p}=0.031$, Log Rank test) (Fig. 1).

\section{Survival Comparison for the Matched Sample}

The OS measured in all patients was 47 months (95\% CI: 34-60). There was a significantly higher OS for group A (56 months, 95\%CI: 37-75) compared to group B (38 months, 95\%CI: 19-56), ( $\mathrm{p}=0.007$, Log Rank test) (Fig. 2).

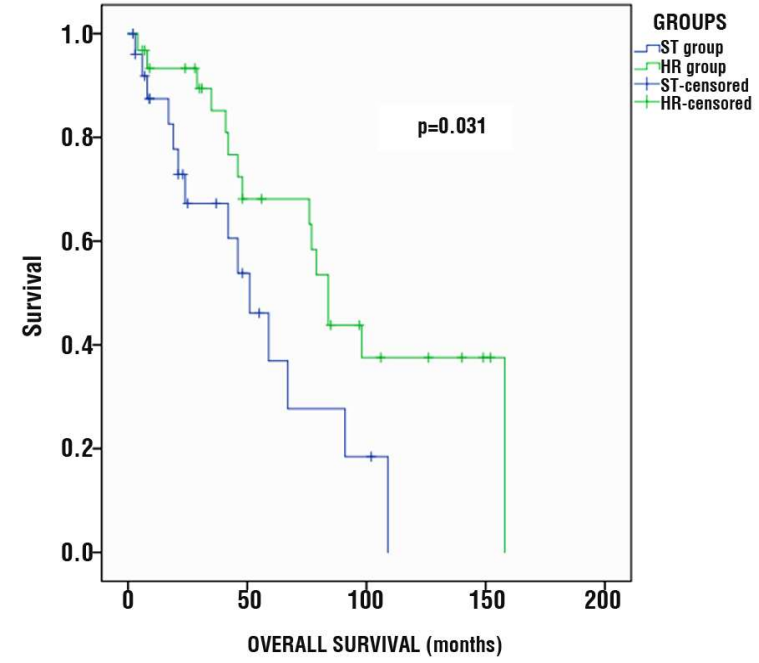

Figure 1. Kaplan-Meyer survival for unmatched groups

\section{Estimating Treatment Effects on the Matched} Sample

All the baseline characteristics were included in a univariate analysis in order to identify the factors associated with improved survival. Afterwards, the multivariate analysis was performed upon those factors that recorded a $\mathrm{p}$-value $<0.05$ in the univariate analysis. After multivariate analysis, only one factor remained independent risk factor: synchronous liver metastases upon diagnosis of primary. Details of the analysis are shown in Table 4.

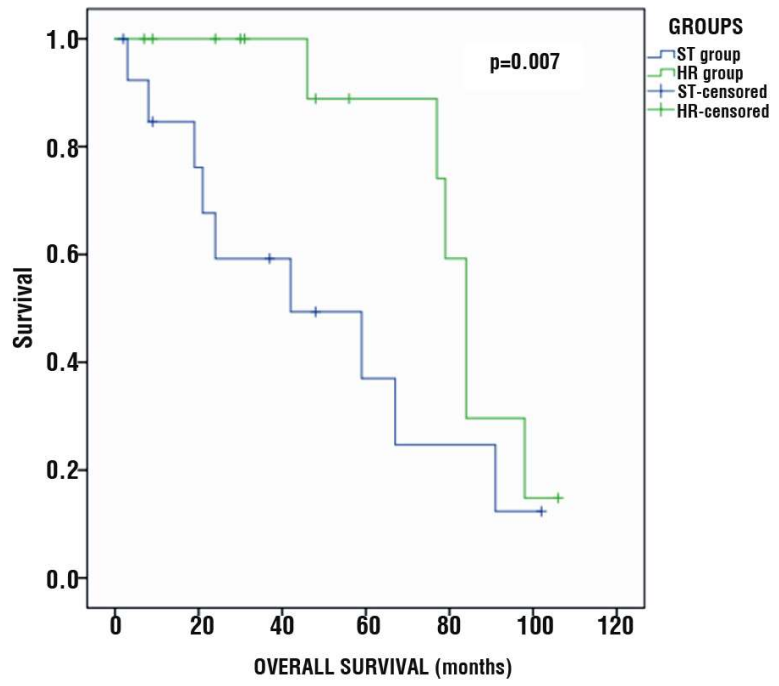

Figure 2. Kaplan-Meyer survival for matched groups 
Table 4. Cox proportional hazard model for factors influencing survival after propensity score matching $(\mathrm{n}=488)$

\begin{tabular}{|c|c|c|c|c|c|c|}
\hline Factors & & Univariate & & & Multivariate & \\
\hline & Hazard Ratio & $95 \% \mathrm{CI}$ & p-value & Hazard Ratio & $95 \% \mathrm{CI}$ & $\mathrm{p}$-value \\
\hline Age (in years) & 1.032 & $0.983-1.082$ & 0.203 & - & - & - \\
\hline Primary Tumor Location & & & & & & \\
\hline Foregut & 0.521 & $0.116-2.340$ & 0.395 & & & \\
\hline Midgut & 1.069 & $0.338-3.376$ & 0.910 & - & - & - \\
\hline Hindgut & 3.062 & $0.589-15.93$ & 0.183 & & & \\
\hline Symptomatic Primary Tumor (no) & 5.440 & $0.607-48.78$ & 0.130 & - & - & - \\
\hline Resection of Primary Tumor (no) & 2.698 & $0.511-14.26$ & 0.243 & - & - & - \\
\hline Primary Tumor Grading & & & & & & \\
\hline G1 & 1.920 & $0.620-5.945$ & 0.258 & - & - & - \\
\hline G2 & 0.521 & $0.168-1.613$ & 0.258 & & & \\
\hline Synchronous Liver Metastases & & & & & & \\
\hline upon Diagnosis of Primary (yes) & 4.923 & 1.269-19.09 & 0.021 & 4.245 & $1.034-17.427$ & 0.045 \\
\hline Synchronous Extrahepatic Metastases & & & & & & \\
\hline upon Diagnosis of Primary (yes) & 0.625 & $0.223-1.751$ & 0.371 & - & - & - \\
\hline Lymph Node Metastasis upon & & & & & & \\
\hline Resection of Primary (no) & 0.624 & $0.222-1.758$ & 0.372 & - & - & - \\
\hline NIH Risk Group & & & & & & \\
\hline Low & 1.079 & $0.130-8.978$ & 0.944 & & & \\
\hline Intermediate & 1.937 & $0.645-5.815$ & 0.238 & - & - & - \\
\hline High & 0.539 & $0.184-1.576$ & 0.258 & & & \\
\hline Number of Hepatic Hetastases & & & & & & \\
\hline Upon Diagnosis & & & & & & \\
\hline Solitary & 6.424 & $1.395-29.57$ & 0.017 & 3.716 & $0.565-24.426$ & 0.172 \\
\hline $2-4$ & 1.777 & $0.367-8.612$ & 0.475 & & & \\
\hline$>4$ & 0.217 & $0.056-0.838$ & 0.027 & 0.600 & $0.105-3.431$ & 0.566 \\
\hline Size of the Largest Liver Metastasis (cm) & 0.934 & $0.765-1.141$ & 0.506 & - & - & - \\
\hline Hepatic Involvement at Diagnosis & & & & & & \\
\hline$<25 \%$ & 1.248 & $0.423-3.681$ & 0.688 & - & - & - \\
\hline $25-50 \%$ & 0.854 & $0.290-2.514$ & 0.774 & & & \\
\hline Location of Liver Metastases (unilobar) & 2.189 & $0.733-6.538$ & 0.160 & - & - & - \\
\hline Grading of Liver Metastasis & & & & & & \\
\hline G1 & 2.295 & $0.750-7.023$ & 0.145 & - & - & - \\
\hline G2 & 0.436 & $0.142-1.333$ & 0.145 & & & \\
\hline Number of Mitoses of Liver Metastasis & 0.933 & $0.834-1.044$ & 0.227 & - & - & - \\
\hline KI-67\% of Liver Metastasis $(>=8)$ & 1.785 & $0.414-7.690$ & 0.437 & - & - & - \\
\hline $\begin{array}{l}\text { Systemic Therapy after Liver Resection } \\
\text { (yes) }\end{array}$ & 1.036 & $0.280-3.836$ & 0.958 & - & - & - \\
\hline $\begin{array}{l}\text { Extrahepatic Metastases upon Diagnosis } \\
\text { of the Liver Metastases (no) }\end{array}$ & 0.665 & $0.235-1.881$ & 0.442 & - & - & - \\
\hline $\begin{array}{l}\text { Response of Liver Metastasis to } \\
\text { Systemic Therapy }\end{array}$ & & & & & & \\
\hline Stable disease & 1.682 & $0.566-5.00$ & 0.350 & & & \\
\hline Partial response & 0.650 & $0.205-2.054$ & 0.463 & - & - & - \\
\hline Complete response & 0.533 & $0.168-1.687$ & 0.284 & & & \\
\hline Systemic Therapy Related Morbidity (yes) & 0.882 & $0.175-4.438$ & 0.879 & - & - & - \\
\hline
\end{tabular}

\section{Discussion}

Our study focused on a special subset of GIST patients originating from a single centre and offered an insight into the role of surgery in this setting, the results suggest that GLM who undergo liver resection following TKI therapy show improved OS compared with those who undergo TKI therapy alone.

In the pre-TKI period, surgical resection alone was associated with 5-year survival of $30-60 \%$ and a median overall survival of only 15 months (7). High liver recurrence rates of up to $60 \%$ were registered (23). With the intro- 
duction of first line TKI therapy, improved patient survival was encountered especially in this advanced disease patient population, therefore the surgical decision-making was modified. Nowadays, the principles of patient selection for liver resection are based primary on tumor biology and patient performance status; and secondly on the disease-free interval, response to medical therapy, presence of extrahepatic disease, the number and size of the metastases, tumor location(s), and the patient level of fitness for surgery. If the patient is fit for surgery and the resection is technically feasible, surgical margin status and TKI response will determine the outcome (6).

Literature reports that margin-negative (R0) resection is associated with a better progression-free survival and 1-year overall survival, as compared with margin-positive resection (29 months vs. 7 months, $p=0.002$ ) (24), respectively ( $100 \%$ vs. $37.5 \%, p=0.001)$ (25). In the present study, R0 resection was achieved in $97 \%$ of group A patients.

It is widely considered that a sustained preoperative response to TKI therapy portends improved benefit from surgical therapy, thus a reduced tumour volume may improve surgical margins (26) (11). NCCN guidelines recommend surgical resection in order to obtain microscopically negative margins, although the need for extensive margins is not specified (27).

The baseline characteristics of both groups were similar. We encounter however a difference that involves: ECOG performance status, Charlson comorbidity score and the number of hepatic metastases upon diagnosis. These differences are to be expected given current clinical practices: group A patients might have presented with conditions that made them more likely candidates for surgery (e.g. better performance status, lower tumour burden) than group B patients. In fact, these factors result from a limitation of this retrospective study: a potential patient selection bias.

To minimise the impact of selection bias on the clinical outcomes in our current study cohort, we used various statistical methods: at first, a propensity score was determined, afterwards the matching function was performed: this methodology has been shown to greatly reduce effect size bias and gives nonrandomised studies experimental design characteristics. However, it's main drawback is: that due to the reduction in sample size, the studies will likely develop a decrease in terms of the statistical power analysis (we obtained a $49 \%$ matching of cases: 28 patients matched, 14 from each group, insufficient for analysis). Covariates used to calculate the propensity score were not only the ones based upon previously published studies (8), instead in order to compare similar patients we considered adequate to introduce: Charlson Comorbidity Score, NIH risk group, hepatic involvement at diagnosis, and grading of liver metastasis.

Secondly, in order to obtain a more robust sample, needed imperatively for the analysis of the differences in survival between the two groups and for identifying the factors associated with improved survival, we performed a bootstrapping selection with Jackknife correction for errors $(18,19)$. Thus, we created an extended sample of 1000 virtual patients, that have identical characteristics as the original sample, on which we performed again the propensity score matching, using the same covariates and caliper as previously mentioned, obtaining a the same matching of cases. It's proper to underline another limit of the study: the fact that the statistical analysis was conducted on a virtual extended matched sample of patients. Never the less, this a proven mehtod in statistical literature $(18,19)$ that implies that the virtual extended sample has the identical characteristics as the original sample. Although it was not employed in medical literature; we consider it feasible in order to reach a sufficient sample size when reporting a single centre experience that involves low-incident tumours. Of course, the best way to eliminate selection bias is a randomised controlled trial, but given that the benefit of surgery has already been strongly suggested in literature, this makes its implementation ethically challenging. This fact was 
evidenced by the 2009 phase III clinical trial (EORTC-62063) performed by the European Organisation for Research and Treatment of Cancer, which evaluated the role of surgery in treating patients with metastatic GIST who responded to imatinib. It was terminated early, due to low participant accrual, reflecting the mixed attitudes of treating physicians to the role of surgery in the treatment of GISTs. In addition, often the results of randomised controlled trials demonstrate insufficient power, and may not necessarily be generalised to a broader patient population. In the future, non-randomised observational data from databases remain a viable option, which could reflect widespread clinical practice, and complement the results of clinical trials.

Thirdly, factors potentially associated with improved survival were analysed using the Cox proportional hazard model with forward stepwise selection (on the original sample and on the matched sample). With multivariate analysis, we found that only one factor affected the patient outcome: synchronous liver metastases upon diagnosis of primary.

Literature agrees nowadays that preoperative TKI therapy for surgically resectable and borderline resectable metastatic GIST is a standard approach, that should be continued up until the time of surgery with resumption in the postoperative period (6).

The optimal timing of surgery continues to be debated. Some recommend to wait, for 3-9 months after the initiation of TKI therapy, since this is the time frame of greatest radiological response (28). Several studies are suggesting that operating during periods of responsive disease or stable disease, compared to progressive disease will to improve outcome $(11,25,29)$. In the contrary, despite the positive response to TKI therapy, the delay of resection leads frequently to the development of secondary mutations, resulting in resistance to imatinib (30). The time of greatest response is considered the moment of successful intervention; therefore the surgeon must closely follow the radiological response (6). The removal of either whole residual tumors or partially resectable tumors, residual after TKI therapy, is considered to bring benefit, because the macroscopic residual lesions usually contain viable tumor cells, and possibly imatinib-resistant clones (8).

\section{Conclusions}

Once the bias of patient selection was reduced by the means of obtaining a more robust sample, and afterwards performing the propensity score matching, patients with hepatic resection as part of the therapeutic strategy show significant improvement in overall survival compared to those undergoing only systemic treatment.

The heterogeneous genetic population of liver metastases from GIST primary tumors leads to the differential success with TKI therapy and resection in achieving prolonged overall survival.

Based on these results, we consider that hepatic resection of GLM following TKI therapy is the current mainstay of treatment strategy for potential cure and prolonged survival, in appropriately selected patients evaluated in an multidisciplinary tumor board.

Also, we consider that patients with stable, or progressive disease following TKI therapy, benefit from surgery (even if complete cytoreduction could not be achieved) in terms of OS, by lowering the risk of developing secondary gene mutations and therefore resistance to TKI therapy.

\section{Acknowledgements}

The authors would like to thank Senior Lecturer Raluca Roxana Purnichescu-Purtan, from the Department of Mathematics, Polytechnic University of Bucharest, Romania, for performing the propensity score matching, and the bootstrapping selection with Jackknife correction for errors.

This material is part of a larger retrospective study of a $\mathrm{PhD}$ thesis, currently under development by Kraft Alin-Alexandru MD, Ph.D student, currently pending full publication, entitled "The surgical treatment of liver 
metastases arising from non-colorectal neoplasia", developed at "Titu Maiorescu" Doctoral School of Medicine, Bucharest, Romania, with Irinel Popescu, University Professor, $\mathrm{PhD}$, as thesis coordinator.

\section{Conflict of Interest}

The authors declare no conflicts of interests.

\section{Ethics of Approval}

For performing this study ethical approval was obtained.

\section{References}

1. Raut CP, Morgan JA, Ashley SW. Current issues in gastrointestinal stromal tumors: incidence, molecular biology, and contemporary treatment of localized and advanced disease. Current opinion in gastroenterology. 2007;23(2):149-58.

2. Xiao B, Peng J, Tang J. Liver surgery prolongs the survival of patients with gastrointestinal stromal tumor liver metastasis: a retrospective study from a single center. Cancer Management and Research 2018:10 6121-6127.

3. DeMatteo RP, Lewis JJ, Leung D, Mudan SS, Woodruff JM, Brennan MF. Two hundred gastrointestinal stromal tumors: recurrence patterns and prognostic factors for survival. Ann Surg. 2000;231(1):51-8.

4. Woodall CE, 3rd, Brock GN, Fan J, Byam JA, Scoggins CR, McMasters KM, An evaluation of 2537 gastrointestinal stromal tumors for a proposed clinical staging system. Arch Surg (Chicago, III : 1960). 2009;144(7): 670-8.

5. Unalp HR, Derici H, Kamer E, Bozdag AD, Tarcan E, Onal MA. Gastrointestinal stromal tumours: outcomes of surgical management and analysis of prognostic variables. Canadian journal of surgery Journal canadien de chirurgie. 2009:52(1):31-8.

6. Morris AD, Maithel SK, Kooby DA. Management of Liver Metastases of Gastrointestinal Stromal Tumors. [book auth.] Chandrajit P. Raut, John T. Mullen Charles R. Scoggins. Gastrointestinal Stromal Tumors Bench to Bedside. s.l. : Springer International Publishing Switzerland, 2017.

7. Joensuu H. Gastrointestinal stromal tumor (GIST). Annals of oncology: official journal of the European Society for Medical Oncology. 2006;17 Suppl 10:x280-6.

8. Park SJ, Ryu MH, Ryoo BY, Park YS, Sohn BS, Kim HJ, et al. The role of surgical resection following imatinib treatment in patients with recurrent or metastatic gastrointestinal stromal tumors: results of propensity score analyses. Ann Surg Onc. 2014:21(13):4211-7.

9. Demetri GD, von Mehren M, Blanke CD, Van den Abbeele AD, Eisenberg B, Roberts PJ, et al. Efficacy and safety of imatinib mesylate in advanced gastrointestinal stromal tumors. N Engl J Med. 2002; 347(7):472-80.

10. Antonescu CR, Besmer P, Guo T, Arkun K, Hom G, Koryotowski B, et.al. Acquired resistance to imatinib in gastrointestinal stromal tumor occurs through secondary gene mutation. Clin Cancer Res. 2005:11(11):4182-90.

11. Raut CP, Posner M, Desai J, Morgan JA, George S, Zahrieh D, et al. Surgical management of advanced gastrointestinal stromal tumors after treatment with targeted systemic therapy using kinase inhibitors. J Clin Oncol. 2006; 24(15):2325-31.
12. Hasegawa J, Kanda T, Hirota S, Fukuda M, Nishitani A, Takahashi T, et al. Surgical interventions for focal progression of advanced gastrointestinal stromal tumors during imatinib therapy. Int J Clin Oncol. 2007;12(3):212-7.

13. Shi YN, Li Y, Wang LP, Wang ZH, Liang XB, Liang H, et.al. Gastrointestinal stromal tumor (GIST) with liver metastases: An 18-year experience from the GIST cooperation group in North China. Medicine (Baltimore). 2017:96(46): e8240.

14. Seesing MF, Tielen $R$, van Hillegersberg $R$, van Coevorden $F$, de Jong $K P$, Nagtegaal ID, et al. Resection of liver metastases in patients with gastrointestinal stromal tumors in the imatinib era: A nationwide retrospective study. Eur J Surg Oncol. 2016 Sep:42(9):1407-13.

15. Dindo D, Demartines N, Clavien PA. Classification of surgical complications: a new proposal with evaluation in a cohort of 6336 patients and results of a survey. Ann Surg. 2004;240(2):205-13.

16. Biologics., Clinical Trial Endpoints for the Approval of Cancer Drugs and. Guidance for Industry. U.S. Department of Health and Human Services Food and Drug Administration. Oncology Center of Excellence. Center for Drug Evaluation and Research (CDER). Center for Biologics Evaluation and Research (CBER). December 2018. https://www.fda.gov/Drugs/Guidance ComplianceRegulatoryInformation/Guidances/default.htm.

17. Eisenhauer EA, Therasse P, Bogaerts J, Schwartz LH, Sargent D, Ford R, et al. New response evaluation criteria in solid tumours: revised RECIST guideline (version 1.1). Eur J Cancer. 2009;45(2):228-47.

18. Efron B, Tibshirani R. Bootstrap Methods for Standard Errors, Confidence Intervals, and Other Measures of Statistical Accuracy. Statist. Sci. 1986;1(1): 54-7.

19. Efron B, Tibshirani R. An Introduction to the Bootstrap. Chapman \& Hall/ CRC Monographs on Statistics \& Applied Probability, CRC Press. 1994.

20. Rosenbaum PR. Design of observational studies. New York: Springer. 2010.

21. Rosenbaum PR, Rubin DB. The central role of the propensity score in observational studies for causal effects. Biometrika. 1983;70:41-55.

22. Rosenbaum PR, Rubin DB. Reducing bias in observational studies using subclassification on the propensity score. J Am Statist Assoc. 1984;79: 516-524.

23. Brudvik KW, Patel SH, Roland CL, Conrad C, Torres KE, Hunt KK, et al. Survival after resection of gastrointestinal stromal tumor and sarcoma liver metastases in 146 patients. J Gastrointest Surg. 2015;19(8):1476-83

24. Zaydfudim V, Okuno SH, Que FG, Nagorney DM, Donohue JH. Role of operative therapy in treatment of metastatic gastrointestinal stromal tumors. J Surg Res. 2012;177(2):248-54

25. Cananzi FC, Belgaumkar AP, Lorenzi B, Mudan $S$. Liver surgery in the multidisciplinary management of gastrointestinal stromal tumour. ANZ J Surg. 2014:84(12):E1-8

26. Mussi C, Ronellenfitsch U, Jakob J, Tamborini E, Reichardt P, Casali PG, et al. Post-imatinib surgery in advanced/metastatic GIST: is it worthwhile in all patients? Ann Oncol. 2010;21(2):403-8.

27. Demetri GD, Benjamin RS, Blanke CD, Blay JY, Casali P, Choi H, et al. NCCN Task Force report: management of patients with gastrointestinal stromal tumor (GIST)--update of the NCCN clinical practiceguidelines. J Natl Compr Canc Netw. 2007:5 Suppl 2:S1-29; quiz S30.

28. Xia L, Zhang MM, Ji L, Li X, Wu XT. Resection combined with imatinib therapy for liver metastases of gastrointestinal stromal tumors. Surg Today. 2010;40(10):936-42.

29. Gronchi A, Fiore M, Miselli F, Lagonigro MS, Coco P. Messina A, et al. Surgery of residual disease following molecular-targeted therapy with imatinib mesylate in advanced/metastatic GIST. Ann Surg. 2007;245(3): $341-6$.

30. Sciot R, Debiec-Rychter M, Daugaard S, Fisher C, Collin F, van Glabbeke M, et al. Distribution and prognostic value of histopathologic data and immunohistochemical markers in gastrointestinal stromal tumours (GISTs): an analysis of the EORTC phase III trial of treatment of metastatic GISTs with imatinib mesylate. Eur J Cancer. 2008;44(13):1855-60. 